\title{
Leaf-fracture properties correlated with nutritional traits in nine Australian seagrass species: implications for susceptibility to herbivory
}

\author{
Carmen B. de los Santos ${ }^{1, *}$, Fernando G. Brun ${ }^{1}$, Yusuke Onoda ${ }^{2,3}$, \\ Marion L. Cambridge ${ }^{4}$, Tjeerd J. Bouma ${ }^{5}$, Juan J. Vergara ${ }^{1}$, José Lucas Pérez-Lloréns ${ }^{1}$ \\ ${ }^{1}$ Department of Biology, University of Cádiz, Campus de Excelencia Internacional del Mar (CEIMAR), PO Box 40, \\ 11510 Puerto Real (Cádiz), Spain \\ ${ }^{2}$ Department of Biological Sciences, Macquarie University, Sydney, New South Wales 2109, Australia \\ ${ }^{3}$ Department of Biology, Faculty of Science, Kyushu University Hakozaki 6-10-1, Fukuoka 812-8581, Japan \\ ${ }^{4}$ School of Plant Biology and the UWA Oceans Institute, The University of Western Australia, 35 Stirling Highway, Crawley, \\ Western Australia 6009, Australia \\ ${ }^{5}$ Netherlands Institute of Ecology (NIOO-KNAW), Centre for Estuarine and Marine Ecology, PO Box 140, 4400 AC Yerseke, \\ The Netherlands
}

\begin{abstract}
Seagrasses are exposed to the constant risk of structural damage due to abiotic factors, such as waves and currents, and biotic factors, e.g. herbivory. Leaf mechanical resistance is therefore essential in protecting plants from structural failure and may also have ecological consequences. For example, mechanical traits of seagrass leaves may play an important role in plantherbivore interactions and food-preferences of herbivores in these ecosystems, as widely reported for terrestrial plants. However, little is known about leaf mechanical resistance against structural damage in seagrasses and how it varies with other traits such as their nutritional value. We analysed the correlation between fracture properties relevant to herbivory and the nutritional value of seagrass leaves, testing the general assumption that species that invest heavily in mechanical resistance (toughening of the leaves) will present low nitrogen and high carbon and fibre contents. Direct measurements of leaf traits were conducted on 9 seagrass species from south-western Australia: (1) leaf-fracture properties from shearing and tearing tests, (2) nutritional values (carbon to nitrogen ratio and fibre content) and (3) morphological and structural traits (specific leaf area and leaf thickness). Results showed that leaf-fracture properties in seagrasses were tightly correlated to their $\mathrm{C}: \mathrm{N}$ ratio, which reflects their nutritional value, thus supporting the general assumption that $\mathrm{C}$ investment is inversely correlated to $\mathrm{N}$ content. This close correlation suggested that patterns of seagrass consumption may be influenced not only by the $\mathrm{C}: \mathrm{N}$ ratio but also by the leaf-fracture properties. Among co-existing seagrasses, we found a continuous spectrum of mechanical and nutritional traits across species, which provides fundamental information about species assembly, herbivore behaviour and ecosystem functions.
\end{abstract}

KEY WORDS: Biomechanics - Herbivory - Nitrogen - Nutritional trait - Leaf toughness · Mechanical resistance

Resale or republication not permitted without written consent of the publisher

\section{INTRODUCTION}

Seagrasses, flowering plants adapted to marine life, are exposed to constant risk of structural damage due to abiotic factors, such as waves and currents, and biotic factors, i.e. herbivory. Mechanical resistance is therefore essential in protecting plants from structural failure (Read \& Stokes 2006 and references therein). Leaf mechanical resistance can be assessed by their fracture properties such as toughness and 
strength, which are traits describing how and under what conditions the leaf will break (reviewed by Aranwela et al. 1999). In plants, high investment in cell wall material and fibres is the basis of leaf toughening and increases the leaf mechanical resistance (Lucas et al. 2000), modifying structural traits such as specific leaf area and leaf dry matter content. Cell wall material and fibres may also have non-mechanical effects, such as nutrient dilution and digestibility reduction (reviewed by Read \& Stokes 2006). Features determining leaf physical integrity such as leaffracture properties, structural traits and fibre content may thus have ecological consequences (Read \& Stokes 2006). For instance, mechanical resistance by leaf toughening have been commonly reported as an effective anti-herbivore defence in terrestrial ecology because it limits the ability of the herbivores to shear or tear the leaves for their intake (Grime et al. 1996, Wright \& Vincent 1996, Pennings et al. 1998, Lucas et al. 2000, Díaz et al. 2001, Sanson et al. 2001, Siska et al. 2002, Cingolani et al. 2005, Sanson 2006).

Recent publications on traits mediating feeding choices of seagrass consumers suggest that structural traits of seagrass leaves (related to leaf mechanical resistance) may play an important role in regulating the plant-herbivore interactions in seagrass ecosystems (Prado \& Heck 2011, Vergés et al. 2011). Other leaf traits, such as the synthesis of chemical feeding deterrents (Zapata \& McMillan 1979, McMillan et al. 1980, Vergés et al. 2007a) or nitrogen content (Vergés et al. 2007b, Prado et al. 2010, Prado \& Heck 2011), have also been reported to influence food selection by seagrass consumers, since their variation may reduce plant quality as food, making leaves less palatable by conferring low attractiveness. Additionally, fibre content also influences herbivore feeding selectivity, since fibrous tissues are difficult to break down mechanically and digest (Klumpp \& Nichols 1983, Lanyon \& Sanson 2006). In general, seagrass living tissues are characterised by their poor nutritional quality and low digestibility, which led to the conclusion that the direct consumption of these plants was insignificant or minimal (Birch 1975, Phillips \& McRoy 1980, Klumpp \& Nichols 1983, Thayer et al. 1984). However, a compilation of recent studies reveals that herbivory on seagrasses has been greatly underestimated and may currently be a significant process in seagrass ecosystems (Valentine \& Heck 1999, Valentine \& Duffy 2006). Yet, very little is known about leaf mechanical resistance against structural damage in seagrasses and how it varies with other leaf traits. This study focuses on the leaf-fracture properties of seagrass leaves and how they correlate to nutritional value (fibre and nitrogen content) and structural traits. We tested the general assumption that species investing heavily in mechanical resistance of leaves will have lower nitrogen and higher carbon and fibre contents, thus influencing biomechanical characteristics, which are likely to have ecological consequences. Specifically, we aimed to: (1) quantify mechanical, nutritional and structural traits of 9 coexisting seagrass species, and (2) examine the associations between these traits that may be contributing various ecological strategies of these seagrass species. Finally, we discuss the potential consequences of our findings for the susceptibility of these seagrass species to herbivory.

\section{MATERIALS AND METHODS}

\section{Location and plant selection}

South-western Australia was selected as the study area for its large number of co-occurring seagrass species (14 species, Carruthers et al. 2007). The study was carried out in mid-November 2008 on 9 seagrass species centred around the geographical area of Perth, including 5 sites along ca. $50 \mathrm{~km}$ of the coastline (Table 1). These species included a wide range of growth strategies, life histories and morphologies (Cambridge 1999) to cover as much variation in the leaf traits as possible: 3 species with a cluster of leaves arising from a stem (Amphibolis antarctica [Labill.] Sonder et Aschers, A. griffithii [J.M. Black] den Hartog, Thalassodendron pachyrhizum den Hartog), 4 species with strap-like leaves (Posidonia australis Hook. f., P. coriacea Kuo \& Cambridge, P. sinuosa Cambridge \& Kuo, and Heterozostera nigricaulis Kuo), 1 species with oval leaves (Halophila ovalis [R. Brown] Hook. f.) and 1 species with terete leaves (Syringodium isoetifolium [Aschers.] Dandy). In addition, there were species from sheltered (e.g. P. sinu$o s a, H$. ovalis) as well as exposed locations ( $P$. coriacea, T. pachyrhizum); short-lived (H. ovalis and $S$. isoetifolium) and long-lived species (Posidonia spp.); 2 species occurring widely in the tropics (H. ovalis and $S$. isoetifolium) and 7 warm temperate species endemic to the southern half of Australia.

Entire specimens (leaves with rhizomes and roots) were collected from sub-tidal sites from 1 to $10 \mathrm{~m}$ deep. Plant material was carefully manipulated after collection to minimise changes in turgence and physical integrity. For transportation to the laboratory of the School of Plant Biology (University of Western Australia, Perth), seagrass shoots were laid out horizontally, wrapped completely in moist tissue and 
Table 1. Nine seagrass species investigated and their collection sites, all in the vicinity of Perth, Western Australia

\begin{tabular}{|c|c|c|c|c|c|}
\hline \multirow[t]{2}{*}{ Species } & \multirow[t]{2}{*}{ Code } & \multirow[t]{2}{*}{ Family } & \multirow[t]{2}{*}{ Location } & \multicolumn{2}{|c|}{ - Coordinates - } \\
\hline & & & & $\mathrm{S}$ & E \\
\hline \multirow{2}{*}{$\begin{array}{l}\text { Amphibolis antarctica (Labill.) } \\
\text { Sonder et Aschers }\end{array}$} & \multirow[t]{2}{*}{$\mathrm{Aa}$} & \multirow[t]{2}{*}{ Cymodoceae } & Garden Island and & $32^{\circ} 14^{\prime} 36.46^{\prime \prime}$ & $115^{\circ} 40^{\prime} 41.93^{\prime \prime}$ \\
\hline & & & Cottlesloe & $32^{\circ} 0^{\prime} 10.62^{\prime \prime}$ & $115^{\circ} 45^{\prime} 1.12^{\prime \prime}$ \\
\hline $\begin{array}{l}\text { Amphibolis griffithii } \\
\text { (J.M. Black) den Hartog }\end{array}$ & Ag & Cymodoceae & Cottesloe & $32^{\circ} 0^{\prime} 10.62^{\prime \prime}$ & $115^{\circ} 45^{\prime} 1.12^{\prime \prime}$ \\
\hline \multirow{2}{*}{$\begin{array}{l}\text { Halophila ovalis } \\
\text { (R. Brown) Hook. f. }\end{array}$} & \multirow[t]{2}{*}{ Ho } & \multirow[t]{2}{*}{ Hydrocharitaceae } & Cockburn Sound and & $32^{\circ} 15^{\prime} 53.54^{\prime \prime}$ & $115^{\circ} 41^{\prime} 52.65^{\prime \prime}$ \\
\hline & & & Swan River & $31^{\circ} 58^{\prime} 54.28^{\prime \prime}$ & $115^{\circ} 49^{\prime} 17.79^{\prime \prime}$ \\
\hline $\begin{array}{l}\text { Heterozostera nigricaulis } \\
\text { Kuo }\end{array}$ & $\mathrm{Hn}$ & Zosteraceae & $\begin{array}{l}\text { Cockburn Sound } \\
\text { (outer part) }\end{array}$ & $32^{\circ} 15^{\prime} 53.54^{\prime \prime}$ & $115^{\circ} 41^{\prime} 52.65^{\prime \prime}$ \\
\hline Posidonia australis Hook. f. & $\mathrm{Pa}$ & Posidoniaceae & Cockburn Sound & $32^{\circ} 15^{\prime} 21.01^{\prime \prime}$ & $115^{\circ} 42^{\prime} 29.04^{\prime \prime}$ \\
\hline $\begin{array}{l}\text { Posidonia coriacea } \\
\text { Kuo \& Cambridge }\end{array}$ & $\mathrm{Pc}$ & Posidoniaceae & Lal Bank & $31^{\circ} 48^{\prime} 33.0^{\prime \prime}$ & $115^{\circ} 43^{\prime} 00.4^{\prime \prime}$ \\
\hline $\begin{array}{l}\text { Posidonia sinuosa } \\
\text { Cambridge \& Kuo }\end{array}$ & Ps & Posidoniaceae & Cockburn Sound & $32^{\circ} 15^{\prime} 21.01^{\prime \prime}$ & $115^{\circ} 42^{\prime} 29.04^{\prime \prime}$ \\
\hline $\begin{array}{l}\text { Syringodium isoetifolium } \\
\text { (Ascher.) Dandy }\end{array}$ & $\mathrm{Si}$ & Cymodoceae & $\begin{array}{l}\text { Cockburn Sound } \\
\text { (outer part) }\end{array}$ & $32^{\circ} 15^{\prime} 53.54^{\prime \prime}$ & $115^{\circ} 41^{\prime} 52.65^{\prime \prime}$ \\
\hline $\begin{array}{l}\text { Thalassodendron pachyrhizum } \\
\text { den Hartog }\end{array}$ & $\mathrm{Tp}$ & Cymodoceae & Garden Island & $32^{\circ} 14^{\prime} 36.46^{\prime \prime}$ & $115^{\circ} 40^{\prime} 41.93^{\prime \prime}$ \\
\hline
\end{tabular}

placed in plastic bags sealed to avoid desiccation, under cool and dark conditions in an ice chest. The following day, the plant material was transported under the same conditions by airplane to the laboratory of the Department of Biological Sciences (Macquarie University, Sydney), where it was immediately submerged in tanks with aerated natural seawater at $20^{\circ} \mathrm{C}$ in a climate-controlled chamber.

\section{Structural traits}

Measurements of leaf traits were taken in healthy and fully-developed but not senescent leaves from at least 5 shoots per species and location. We cut a leaf fragment of $\sim 5 \mathrm{~cm}$ length and measured the fresh weight $(\mathrm{FW} ; \mathrm{g})$ and projected area $\left(\mathrm{PA}_{i} \mathrm{~mm}^{2}\right)$ using image analysis software (ImageJ) after scanning the fragment. Subsequently, we determined blade width $\left(\mathrm{Wd}_{i} \mathrm{~mm}\right)$ and thickness $(\mathrm{Th} ; \mathrm{mm})$ or diameter $(\mathrm{D}$; $\mathrm{mm}$ ) with digital callipers and a thickness gauge to calculate the blade cross-sectional area $\left(\mathrm{CA}_{i} \mathrm{~mm}^{2}\right)$, assuming the cross-section had either a rectangular or round shape. After measuring the mechanical properties (see below), these leaf fragments were freeze-dried and used to measure their dry weight (DW; g) with a precision balance. The whole fragment volume $\left(\mathrm{V}_{i} \mathrm{~mm}^{3}\right)$ of each sample was estimated considering the leaf fragment length $(\mathrm{L} ; \mathrm{mm})$ and the CA. Specific leaf area (SLA; $\left.\mathrm{m}^{2} \mathrm{~kg}^{-1} \mathrm{DW}\right)$ was then calculated as the leaf fragment area divided by its correspondent DW, and leaf dry matter content $(\mathrm{LDMC} ; \%)$ as the percentage of DW in FW.

\section{Mechanical traits}

Leaf-fracture properties were evaluated by 2 tests (tearing and shearing tests) and expressed at 2 levels: (1) whole-leaf mechanical traits, that is, total quantity of force or work needed to tear or shear a single leaf blade, which depends on the leaf size and its mechanical properties at the material level; (2) material mechanical traits, normally called 'material properties', which are inherent properties to the material, normalized by leaf volume or leaf CA. Regarding the ecological significance of these traits, whole-leaf mechanical traits indicate the work or force in absolute terms to shear or tear a single leaf blade by, for example, a herbivore, whereas material properties show invested work or force for an amount of material ingested, giving an idea of the cost-efficiency in the feeding process.

The leaf mechanical properties were measured within $4 \mathrm{~d}$ of sampling and the specimens tested in the sequence that they were collected so that the time of storage was homogeneous among species. Prior to the measurements, leaves were lightly and carefully cleaned of epiphytes and debris. The first outermost fully-developed leaf of the plant shoot was selected (normally the second youngest leaf), and a portion of the blade leaf (4 to $5 \mathrm{~cm}$ above the ligule, not including the leaf sheath) was cut for testing. These portions were the same used for the measurements of the structural traits described in the previous section.

Shearing test measures the force required for foliar breakage (Wright \& Vincent 1996, Aranwela et al. 1999). We used a purpose-built shearing machine 
with a constant cutting angle $\left(20^{\circ}\right)$ and speed (see Wright \& Cannon 2001 for more details). Although this test was not intended to mimic any specific herbivore-induced stress, it provides an indication of physical resistance (Wright \& Cannon 2001) and it has been identified as 1 of the best ways to measure leaf toughness (Sanson et al. 2001). The test was conducted in 2 directions, transverse and longitudinal, across the leaf ( $\mathrm{n}=5$ to 11 for each species and test) except for Syringodium isoetifolium, where only transversal testing was possible due to its terete morphology. During the test, a force to displacement curve was monitored, and the absolute work-toshear $\left(\mathrm{W}_{\mathrm{SA}} ; \mathrm{mJ}\right)$ needed to cut the specimen was calculated as the area under this curve (Fig. 1). This amount of work was expressed per unit fracture area (CA), to calculate the specific work-to-shear $\left(\mathrm{W}_{\mathrm{SS}}\right.$ i $\mathrm{J} \mathrm{m}^{-2}$; Read \& Sanson 2003). As the whole leaf was cut transversally during the test, the measured $\mathrm{W}_{\mathrm{SA}}$ and $\mathrm{W}_{\mathrm{SS}}$ reflect a gross measure of all of the components of the leaf, i.e. the work done to shear the lamina, including the leaf veins and midribs, if present (Sanson et al. 2001; our Fig. 1).

The tensile (tearing) test was carried out on another set of leaf portions similarly selected as described for the shearing test. The mechanical properties in tension were measured with an Instron testing machine (model 5542) and the BlueHill@ software (v. 2.18) with a $500 \mathrm{~N}$-load cell and pneumatic action grips (model 2712). The tests were conducted to the long axis of the leaf, including the midrib in the case of Halophila ovalis. The leaves were clamped individually into the grips of the tensometer with the mountings from 10 to $135 \mathrm{~mm}$ apart (depending on the species size), with the exact distance measured to the closest $1 \mathrm{~mm}$. When necessary, the inner part of the grips was covered with rubber to avoid slippage of the leaf. Once clamped in the grips, the leaf specimens were stretched at a constant velocity of $10 \mathrm{~mm}$ $\min ^{-1}$, while the displacement $(\delta, \mathrm{mm})$ and the load force $(\mathrm{F}, \mathrm{N})$ were recorded every $0.1 \mathrm{~s}$ until they broke, when the maximum force (absolute force-totear, $\mathrm{F}_{\mathrm{TA}}, \mathrm{N}$ ) was recorded. From the force-displacement curve and the size traits, we obtained the following mechanical properties: (1) $\mathrm{F}_{\mathrm{TA}}(\mathrm{N})$, the maximum force that the specimen can bear before breaking; (2) specific force-to-tear $\left(\mathrm{F}_{\mathrm{TS}}, \mathrm{N} \mathrm{mm}^{-2}\right)$, the maximum force per unit of CA needed for the specimen to break, which is equivalent to the property known as 'tensile strength' or 'breaking stress' in engineering (Gere \& Goodno 2009); (c) absolute work-to-tear $\left(\mathrm{W}_{\mathrm{TA}}, \mathrm{mJ}\right)$, i.e. the work needed to break the leaf, calculated as the area under the forcedisplacement curve; $(\mathrm{d})$ specific work-to-tear $\left(\mathrm{W}_{\mathrm{TS}}\right.$
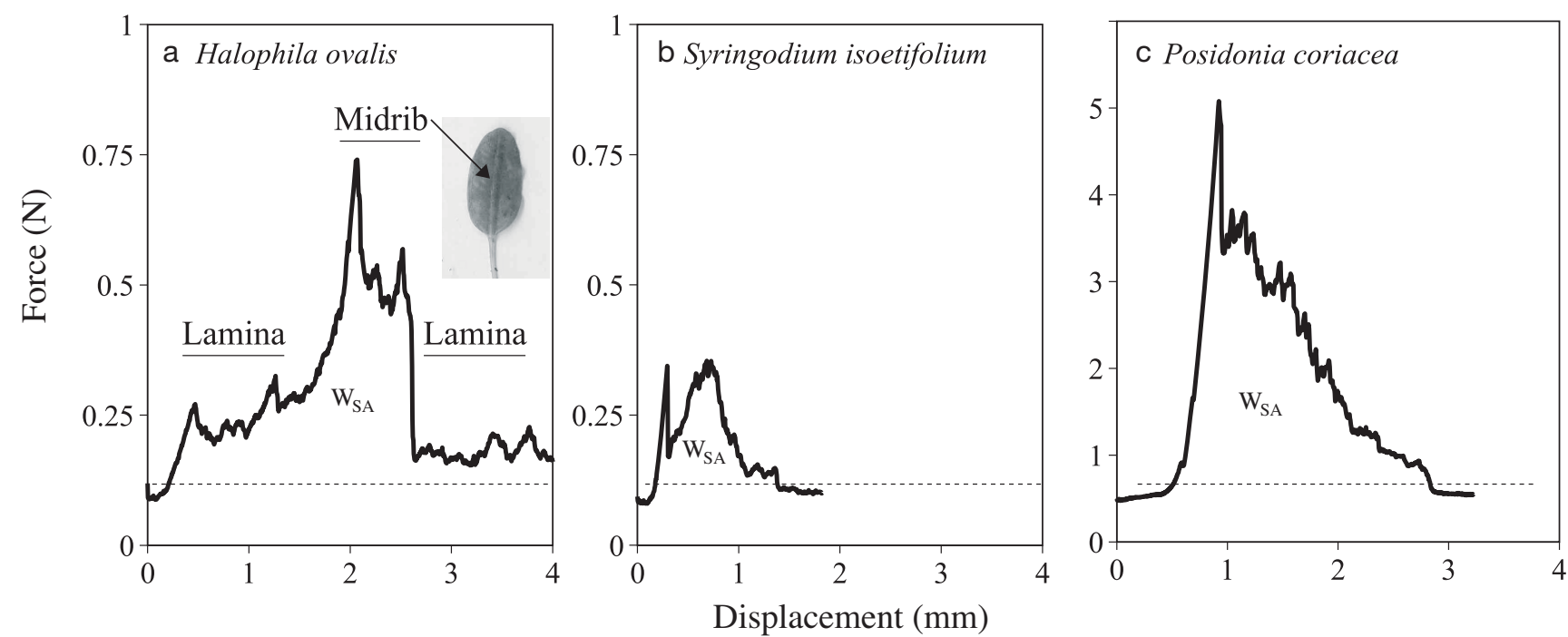

Fig. 1. Halophila ovalis, Syringodium isoetifolium and Posidonia coriacea. Representative force-displacement curves from a shearing test for 3 different species. The displacement ( $x$-axis) is the distance travelled by the horizontal blade. The full area under the curve is used to estimate absolute work-to-shear ( $\left.\mathrm{W}_{\mathrm{SA} ;} \mathrm{mJ}\right)$. The shearing test can be used to capture an image of the variation in fracture properties along a leaf transect (Aranwela et al. 1999). (a) H. ovalis leaf, showing the force applied to cut transversally the lamina or leaf blade (with cross-veins) and the increase when the cutting blade of the machine reaches the midrib (more energy needed to cut). (b) In S. isoetifolium, the force decreases when the cutting blade is reaching the aerenchyma in the leaf centre. (c) In P. coriacea, the highest force across the leaf is reached when the cutting blade first touches the outer part of the leaf; note that the $y$-axis scale is 6 -fold higher than scales used for panels (a) and (b). Dotted line: baseline of the cutting device, i.e. the force without cutting any sample 
$\mathrm{J} \mathrm{m}^{-3}$ ) is the $\mathrm{W}_{\mathrm{TA}}$ normalized by the tissue volume $(\mathrm{V})$, which is also called 'tensile toughness'. Tests were made on 5 to 15 replicates per species, excluding the specimens that slipped during the test or broke close to or at the grips.

\section{Nutritional traits}

After measuring the leaf-fracture properties, the epiphyte-free portions of leaves from each species were freeze-dried and pulverized in a ball-grinder. Subsamples of dried biomass were then used for the determination of total $\mathrm{C}$ and $\mathrm{N}$ content (\% DW) using a Perkin-Elmer 2400 elemental analyser. C:N ratio was calculated based on dry biomass. A second subsample of the dried biomass was used to determine the neutral detergent fibre content (NDF; method modified from Van Soest et al. 1991). Samples of 20 to $30 \mathrm{mg}$ of dry biomass were heated to boiling $\left(100^{\circ} \mathrm{C}\right)$ in $2 \mathrm{ml}$ of neutral detergent for $1 \mathrm{~h}$, followed by centrifuging $(2500 \times g$, $5 \mathrm{~min})$. The pellet was kept in the tube, washed and centrifuged $(2500 \times g, 5 \mathrm{~min})$ with distilled water $(\times 2)$, ethanol $(\times 2)$ and acetone $(\times 1)$. The final pellet, free of non-cell wall components and chlorophyll, was dried overnight in an oven at $60^{\circ} \mathrm{C}$ and weighed again. The amount of fibre for each sample was obtained by the difference in mass and expressed as fibre percentage of dry biomass (\% or $\mathrm{g}$ of fibre per $100 \mathrm{~g}$ of dry biomass). The NDF content is referred to as 'fibre content' hereafter. For each species, 3 to 6 replications were made.

\section{Data and statistical analysis}

The interspecific variability in traits was assessed by the coefficient of variation (CV). Non-parametric 1-way analysis of variance (Kruskal-Wallis test), followed by non-parametric multiple comparison test (Behrens-Fisher test for all pairs), was used to compare leaf traits among species since data did not satisfy analysis of variance assumptions (Shapiro-Wilk test for normality and Levene's test for homoscedasticity) even after transformations. We constructed a correlation matrix with Spearman's coefficient to all pairs of traits. A principal component analysis (PCA) was conducted with a selection of a suite of key variables in each trait group to observe the relationship of species in relation to these variables. A critical level of 0.05 was used for all hypothesis tests. Statistical analyses were computed with R 2.11.1 (R Development Core Team 2010).

\section{RESULTS}

\section{Comparison across species}

Leaf traits varied significantly among species (Tables $2 \& 3$ ), and inter-species variability tended to be higher in the mechanical traits than in the nutritional traits (Tables $3 \& 4$ ). In this inter-specific comparison, the 2 cosmopolitan species Syringodium isoetifolium and Halophila ovalis had the lowest C and NDF and the highest $\mathrm{N}$ contents in their leaves, thus the lowest $\mathrm{C}: \mathrm{N}$ ratio $(<17$; Table 2, Fig. 2). In structural traits, $H$. ovalis had the highest SLA,

Table 2. Nutritional and structural leaf traits. Values are means \pm SD of replicates $(n=3$ for nutritional traits and $n=5$ to 15 for structural leaf traits). C: leaf carbon content, N: leaf nitrogen content, C:N ratio (dry weight, DW-based), NDF: leaf neutral detergent fibre content, LDMC: leaf dry matter content, SLA: specific leaf area, Th: leaf thickness, CV: coefficient of variation, p: statistical significance associated with Kruskal-Wallis test for testing equality of medians among species

\begin{tabular}{|c|c|c|c|c|c|c|c|}
\hline \multirow{2}{*}{ Species } & \multicolumn{4}{|c|}{ Nutritional traits } & \multirow{2}{*}{\multicolumn{2}{|c|}{$\begin{array}{c}\text { - Structural traits } \\
\text { SLA } \\
\left(\mathrm{m}^{2} \mathrm{~kg}^{-1} \mathrm{DW}\right)\end{array}$}} & \multirow[b]{2}{*}{$\begin{array}{c}\mathrm{Th} \\
(\mathrm{mm})\end{array}$} \\
\hline & $\begin{array}{c}\mathrm{C} \\
(\% \mathrm{DW})\end{array}$ & $\begin{array}{c}\mathrm{N} \\
(\% \mathrm{DW})\end{array}$ & $\mathrm{C}: \mathrm{N}$ ratio & $\begin{array}{c}\text { NDF } \\
(\% \text { DW) }\end{array}$ & & & \\
\hline Amphibolis antarctica & $32.0 \pm 1.5$ & $1.7 \pm 0.2$ & $21.7 \pm 1.6$ & $43.5 \pm 2.6$ & $23.8 \pm 2.3$ & $19.1 \pm 2.6$ & $0.16 \pm 0.01$ \\
\hline Amphibolis griffithii & $30.6 \pm 1.1$ & $1.9 \pm 0.3$ & $19.2 \pm 2.3$ & $47.8 \pm 0.8$ & $27.0 \pm 4.4$ & $16.1 \pm 2.6$ & $0.21 \pm 0.02$ \\
\hline Halophila ovalis & $28.9 \pm 0.8$ & $2.2 \pm 0.2$ & $15.6 \pm 1.9$ & $43.9 \pm 0.5$ & $23.5 \pm 10.8$ & $36.5 \pm 6.4$ & $0.09 \pm 0.01$ \\
\hline Heterozostera nigricaulis & $32.1 \pm 0.4$ & $1.8 \pm 0.1$ & $20.8 \pm 1.2$ & $55.2 \pm 1.4$ & $33.2 \pm 15.6$ & $28.6 \pm 13.2$ & $0.17 \pm 0.03$ \\
\hline Posidonia australis & $33.0 \pm 0.5$ & $1.2 \pm 0.1$ & $31.4 \pm 2.3$ & $57.2 \pm 1.2$ & $22.7 \pm 1.7$ & $14.2 \pm 2.0$ & $0.35 \pm 0.06$ \\
\hline Posidonia coriacea & $32.3 \pm 2.0$ & $0.8 \pm 0.3$ & $52.3 \pm 15.3$ & $58.4 \pm 0.8$ & $17.2 \pm 0.6$ & $8.2 \pm 1.3$ & $1.03 \pm 0.16$ \\
\hline Posidonia sinuosa & $34.5 \pm 0.4$ & $1.3 \pm 0.3$ & $30.7 \pm 5.7$ & $59.5 \pm 1.4$ & $23.9 \pm 5.4$ & $18.9 \pm 4.0$ & $0.25 \pm 0.03$ \\
\hline Syringodium isoetifolium & $26.5 \pm 0.5$ & $2.0 \pm 0.1$ & $15.4 \pm 0.6$ & $38.1 \pm 1.8$ & $12.8 \pm 0.5$ & $8.5 \pm 0.7$ & $1.21 \pm 0.22$ \\
\hline Thalassodendron pachyrhizum & $31.2 \pm 0.7$ & $1.3 \pm 0.1$ & $28.0 \pm 2.3$ & $49.4 \pm 1.1$ & $24.4 \pm 1.7$ & $22.2 \pm 2.3$ & $0.19 \pm 0.04$ \\
\hline CV inter-species (\%) & 8 & 28 & 44 & 15 & 25 & 48 & 102 \\
\hline $\mathrm{p}$ & $<0.001$ & $<0.001$ & $<0.001$ & $<0.001$ & $<0.001$ & $<0.001$ & $<0.001$ \\
\hline
\end{tabular}



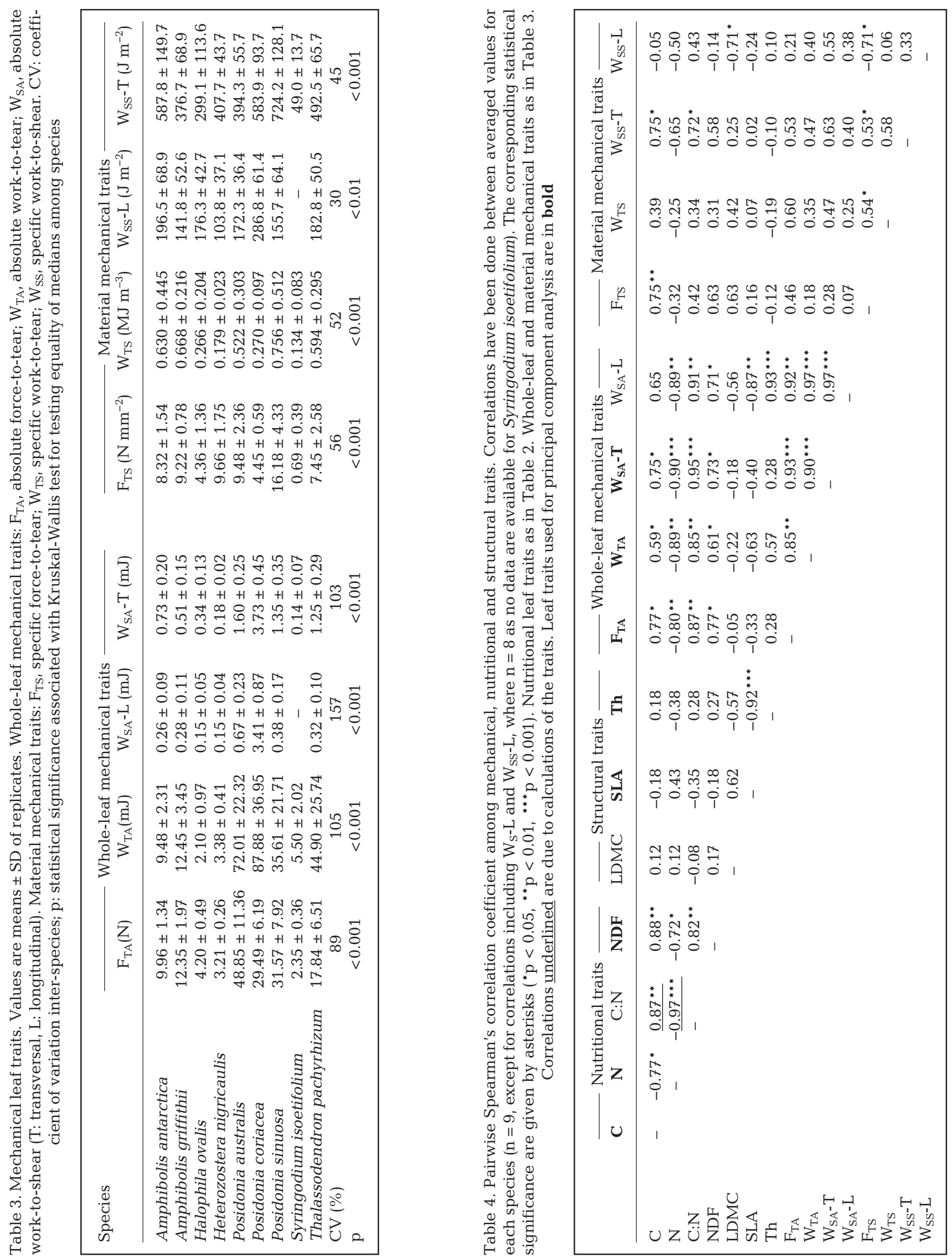

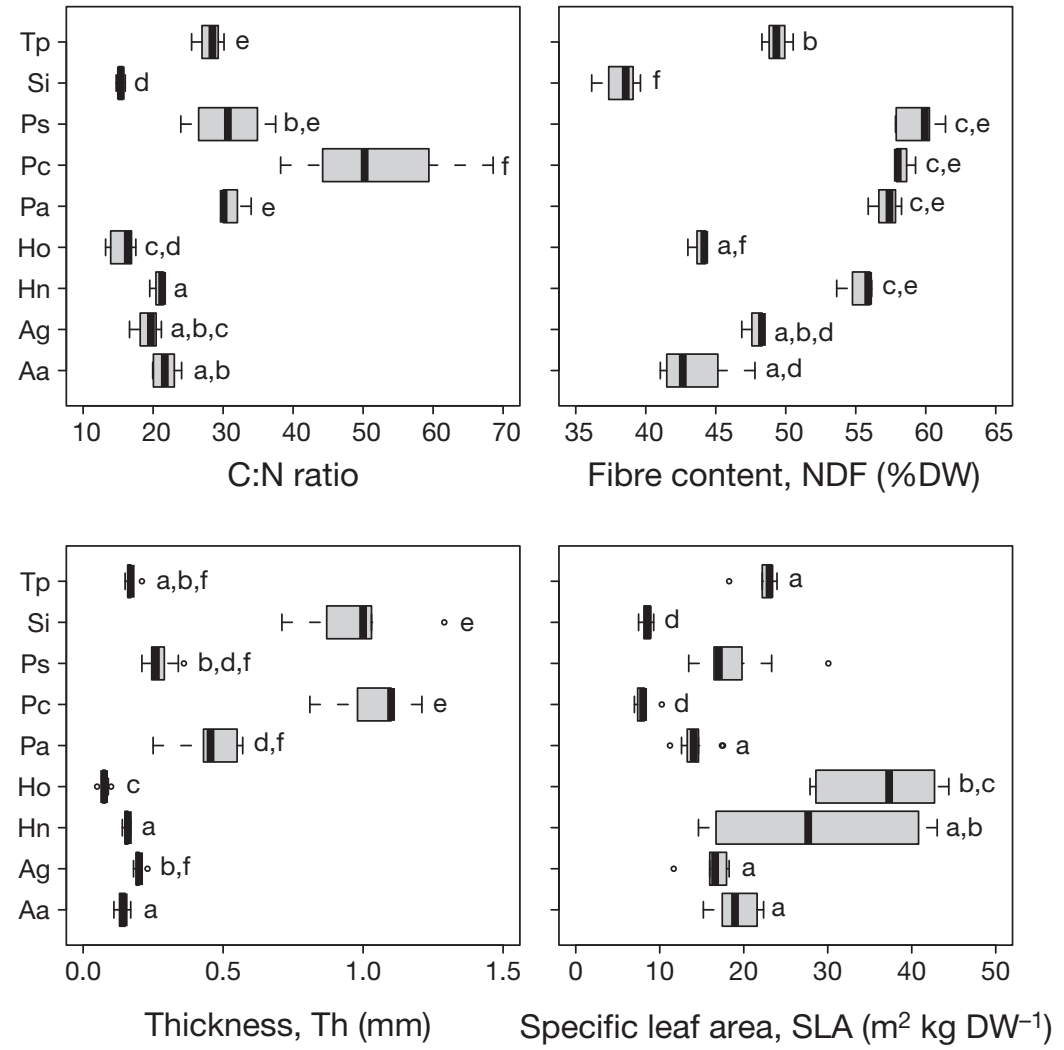

Fig. 2. Differences across species for selected nutritional and structural traits. Lettering indicates species with significantly different values for the variables at $p<0.05$ (non-parametric multiple comparisons). Mid-line is the median, box limits are the 25th and 75th quartiles, whiskers show the $1.5 \mathrm{in}-$ terquartile range, and points are the observations out of this range. NDF: neutral detergent fibre content. Species on the $y$-axis: Tp, Thalassodendron pachyrhizum; Si, Syringodium isoetifolium; Ps, Posidonia sinuosa; Pc, P. coriacea; $\mathrm{Pa}$, P. australis; Ho, Halophila ovalis; Hn, Heterozostera nigricaulis; Ag, Amphibolis antarctica; Aa, A. griffithii

whereas $S$. isoetifolium, with a fleshy, cylinder-like leaf, had the lowest SLA and LDMC (Table 2, Fig. 2). In mechanical traits, $S$. isoetifolium and $H$. ovalis presented the lowest values for most of the whole-leaf and material properties (Table 2). In contrast, the 3 species of the genus Posidonia, and especially P. coriacea, reached the lowest $\mathrm{N}$ content and the highest $\mathrm{C}$ and fibre content values in their foliar tissue (Table 2, Fig. 2). This genus also showed the highest values in all of the whole-leaf mechanical traits (Table 3, Fig. 3); for instance, the absolute force needed to tear a $P$. coriacea leaf was $35 \mathrm{~N}$ on average, 25 times higher than the force needed for $S$. isoetifolium. The other species with a similar morphology consisting of a cluster of leaves arising directly from a vertical stem (Amphibolis spp., Heterozostera nigricaulis and Thalassodendron pachyrhizum) had nutritional values in between the Posidonia spp. (high C:N ratio, high NDF) and the 2 smaller, more ephemeral species, $H$. ovalis and $S$. isoetifolium, (C:N ratio <17, low NDF; Fig. 2), with a similar pattern observed for mechanical traits (Fig. 3). The comparison of transverse versus longitudinal toughness across the species indicated that 2 to 4 times more work was required to fracture leaves transversely than longitudinally, except for $P$. coriacea, where a similar force was needed to cut the leaf in both directions (Table 3). In longitudinal section, almost all species grouped together, except for the Posidonia spp. group (Fig. 3).

\section{Leaf trait intercorrelation}

We obtained a correlation matrix with all pairwise comparisons among the leaf traits (Table 4). Overall, we observed strong correlations among nutritional traits, among whole-leaf mechanical traits and between nutritional traits and whole-leaf mechanical traits (Table 4). Among the nutritional variables, the fibre content (NDF) was positively correlated to $\mathrm{C}$ content and negatively to $\mathrm{N}$ across the species (Table 4 ). As a result, NDF was positively correlated to the C:N ratio. The whole-leaf mechanical traits such as $\mathrm{F}_{\mathrm{TA}}, \mathrm{W}_{\mathrm{TA}}$ and $\mathrm{W}_{\mathrm{SA}}$ were positively correlated with the $\mathrm{C}: \mathrm{N}$ ratio and NDF (Table 4). These correlations mean that the leaves that need a high amount of work or force to be cut or torn present a higher proportion of fibres and $\mathrm{C}$, and a lower proportion of $\mathrm{N}$. Additionally, we found stronger correlations among whole-leaf mechanical traits, such as $\mathrm{W}_{\mathrm{TA}}, \mathrm{F}_{\mathrm{TA}}$ and $\mathrm{W}_{\mathrm{SA}}$, than among material properties (Table 4 ).

After analysing the correlations between all pairs of traits, we selected key variables in each group of traits including: Th and SLA; $\mathrm{C}, \mathrm{N}$ and fibre contents $(\mathrm{NDF})$; and 3 whole-leaf mechanical properties $\left(\mathrm{F}_{\mathrm{TA}}\right.$, $\mathrm{W}_{\mathrm{TA}}$ and absolute work-to-shear in the transversal direction $\mathrm{W}_{\mathrm{SA}^{-}}-\mathrm{T}$ ) for PCA. We did not include shearing test data in the longitudinal direction, as they were not measured in Syringodium isoetifolium. We retained 2 components explaining $87 \%$ of the variance. The leading component (PC1, 61.6\% of variance) was negatively correlated with $\mathrm{N}$ and posi- 

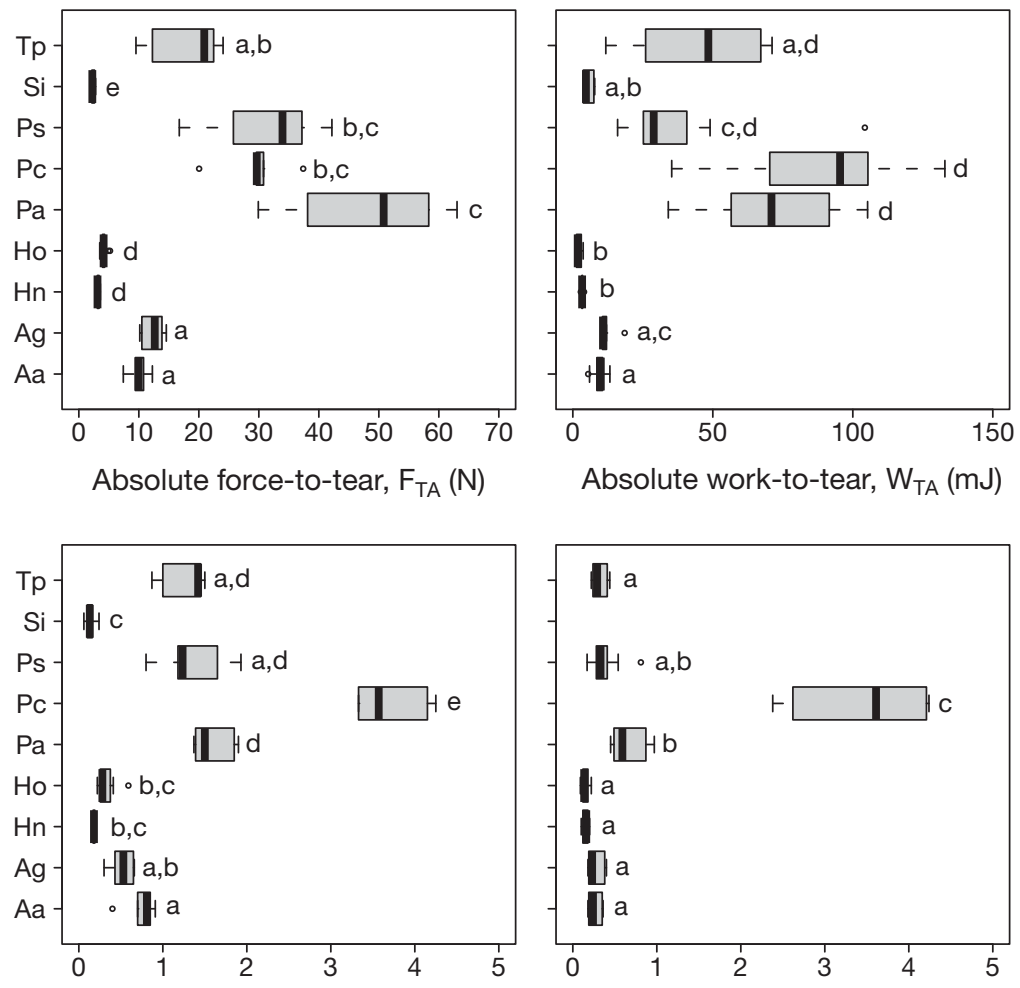

Absolute work-to-shear, $\mathrm{W}_{\mathrm{SA}}-\mathrm{T}(\mathrm{mJ})$ (transverse)

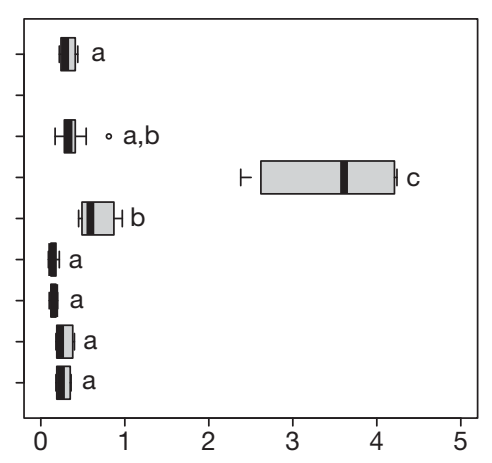

Absolute work-to-shear, $\mathrm{W}_{\mathrm{SA}}$-L (mJ) (longitudinal)

Fig. 3. Differences across species for whole-leaf mechanical leaf traits. Lettering indicates species with significantly different values for the variables at $\mathrm{p}<0.05$ (non-parametric multiple comparisons). Box plots and abbreviations as in Fig. 2

tively with the whole-leaf mechanical properties, whereas PC2 (25.9\% of variance) was negatively associated with $\mathrm{C}, \mathrm{NDF}$ and SLA and positively with blade thickness (Fig. 4). NDF presented similar loadings in both components. S. isoetifolium and Halophila ovalis displayed the lowest scores for PC1, whereas Posidonia spp. exhibited the highest (Fig. 4). Amphibolis spp., Heterozostera nigricaulis and Thalassodendron pachyrhizum (all species with a similar morphology, a cluster of leaves arising from a vertical stem), were situated in an intermediate position. In reference to $\mathrm{PC} 2$, in which thickness, SLA and C were strongly associated, $P$. coriacea and $S$. isoetifolium had a similar score due to their analogous thickness and SLA (Fig. 4).

\section{DISCUSSION}

Our results showed that leaf-fracture properties and nutritional traits were negatively and tightly inter-correlated in seagrasses, indicating that species with high mechanical resistance (that is, more force or work is needed to shear or tear the leaves) tend to exhibit a low leaf nutritional value (high $\mathrm{C}: \mathrm{N}$, high fibre content). Similar correlations have been described for terrestrial plants, suggesting that there has been a parallel selection among species for a combination of certain traits both in terrestrial and aquatic environments (Pérez-Harguindeguy et al. 2003, Read \& Stokes 2006, Read et al. 2009, Molinari \& Knight 2010). The correlations reflect a mixture of direct and indirect causal relationships between leaf traits (Wright et al. 2004), as $\mathrm{C}$ is the main building element of supporting tissue. Therefore, a high fraction of $\mathrm{C}$ is used for the structural carbohydrates forming cell walls and fibre bundles, explaining the correlation between $\mathrm{C}$ and leaf reinforcement. Accordingly, high C:N ratios (i.e. poor nutritional value) are found in species with tough tissues, since the primary source of leaf toughening in plants is the composite cell wall and fibres (Lucas et al. 2000).

Mechanical resistance and fibre content are leaf traits that confer protection against a range of mechanical damage, both abiotic and biotic (reviewed by Read \& Stokes 2006). The leaf mechanical resistance may be important in the adaptation to abiotic factors such as water motion, and it may be the result of the plant life-history strategy (persistence

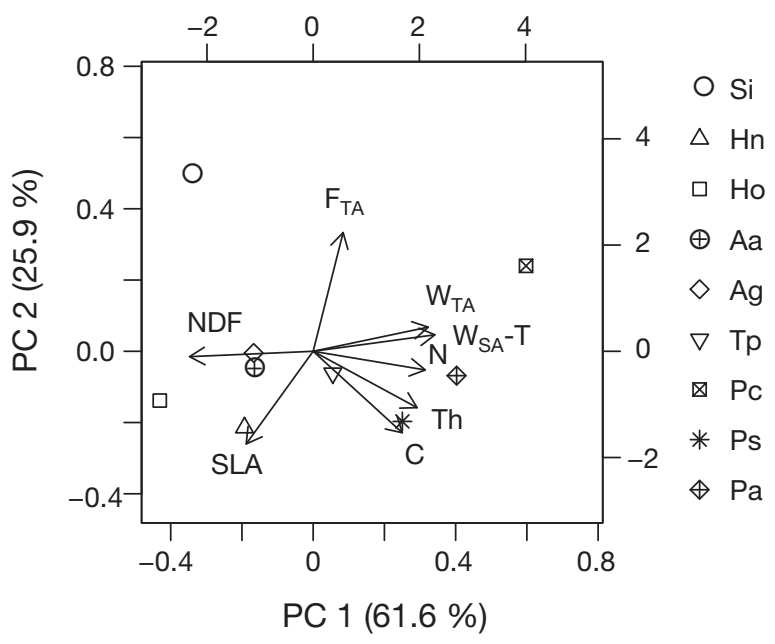

Fig. 4. Principal component analysis with the projection of the 8 variables (arrows) and 9 species (each represented by a different symbol). Abbreviations as in Figs. 2 \& 3 
versus productivity). For instance, Syringodium isoetifolium and Halophila ovalis often experience low mechanical stress as they live in sheltered places or form the understorey beneath other seagrasses (Cambridge \& Lambers 1998), so their leaves resist low mechanical loads and have a relatively low amount of fibres, in comparison with other seagrasses. In contrast, Posidonia spp. have large amounts of foliar fibres which provide mechanical support to withstand the mechanical forces from strong water movement.

The described correlations of leaf traits may have implications in other ecological aspects. For instance, both types of traits, mechanical and nutritional, have been described as factors underlying the potential palatability of seagrass leaves and the food preference of their consumers. Some studies actually found a positive correlation between seagrass leaf $\mathrm{N}$ content and preference by herbivores (e.g. Bjorndal 1980, Zieman et al. 1984, McGlathery 1995, Preen 1995, Goecker et al. 2005), although other studies showed negative correlations (Mariani \& Alcoverro 1999, Valentine \& Heck 2001, Kirsch et al. 2002, Vergés et al. 2007b, White et al. 2011). Preferences of seagrass consumers may thus be influenced by factors other than $\mathrm{N}$, such as fibre content or leaf-fracture properties, which may be more relevant. Vergés et al. $(2007 \mathrm{a}, 2011)$ found that sea urchins preferentially consumed the most nutritious but less chemically defended leaf tissues only when structural defences were removed in artificial diet experiments. Along the same lines, Prado \& Heck (2011) suggested that structural plant features are the most important factors driving discrimination between seagrass species by omnivorous fish, whereas strict herbivores make feeding decisions influenced by nutritional characteristics. These observations suggest that both mechanical and nutritional traits may determine the food-preferences of seagrass consumers.

Among the 9 coexisting seagrass species, we found a continuous spectrum of mechanical and nutritional leaf traits. According to this continuum, we could expect a preference by seagrass consumers toward the species with high nutritional value and low mechanical resistance. Previous studies reported herbivory preference for pioneering over climax species (Lanyon 1991, Preen 1995, Aragones 1996, Mariani \& Alcoverro 1999). In our study, results showed that the small, cosmopolitan and fast-growing species Syringodium isoetifolium and Halophila ovalis (Kirkman 1985, Cambridge \& Lambers 1998, Cambridge 1999) may be more susceptible to herbivory because of their higher $\mathrm{N}$ and lower $\mathrm{C}$ and fibre con- tents, as well as having 'tender' tissues (i.e. low mechanical resistance). In fact, there is an extensive literature on the grazing of the cosmopolitan species (H. ovalis, Halodule uninervis and $S$. isoetifolium) by dugongs (Lanyon et al.1989, Preen 1995, Nakaoka \& Aioi 1999) and green turtles (Bjorndal 1980, KuiperLinley et al. 2007) in tropical seagrass meadows. These are fast-growing species that do not invest in leaf toughening as much as the large, long-lived Posidonia spp. (Cambridge \& Lambers 1998, Cambridge 1999) because this would be a trade-off to photosynthesis investment in growth. These longlived species might be less susceptible to herbivory given their structural reinforcement as a mechanism of persistence, which is expressed as high C content, low N content and tough leaves. Amphibolis spp., Heterozostera nigricaulis and Thalassodendron pachyrhizum (all species with a similar morphology, a cluster of leaves arising from a vertical stem) were situated in an intermediate position between the short- and long-lived species.

We conducted a literature survey on studies of seagrass consumers to assess their preferences for the 9 seagrass species included in our study (Table 5). Information is lacking about herbivory pressure on half of the species (e.g. Thalassodendron pachyrhizum, Heterozostera nigricaulis, Halophila ovalis and Syringodium isoetifolium). Low levels of direct grazing were reported for leaves of Posidonia spp. and Amphibolis spp., with periphyton, epiphytes and ageing leaves with high epiphyte or epifauna loads being the preferred food sources in Western and Eastern Australian seagrass beds (Table 5). We found a few studies reporting a preference for $A$. griffithii and P.sinuosa over A. antarctica and P. coriacea (for herbivorous fishes; MacArthur \& Hyndes 2007, White et al. 2011) and young tissues of $P$. australis over P. sinuosa (for isopods; Brearley \& Walker 1995, Brearley et al. 2008). In fact, Posidonia spp. appear to contribute very little directly to the secondary production of higher trophic levels in Western Australian meadows (Table 5).

Halophila ovalis and Syringodium isoetifolium were the only 2 species in our study characterised by a $\mathrm{C}: \mathrm{N}$ ratio $<17$, which is considered necessary in animal nutrition (Russel-Hunter 1970), and presenting weak or 'soft' tissues, i.e. with a low mechanical resistance to herbivore attack. In contrast, we found that the majority of the species, specially Posidonia spp., presented a high $\mathrm{C}: \mathrm{N}$ ratio, presumably explained by their fibre-reinforced or tough leaves. Valentine \& Duffy (2006, p. 469) suggested that 'it is unlikely that high $\mathrm{C}: \mathrm{N}$ ratios $(>17)$ by themselves are 
Table 5. Literature information on the leaf consumption in the seagrass species included in the study. Geographical areas include both Western and Eastern Australia

\begin{tabular}{|c|c|c|c|c|c|}
\hline $\begin{array}{l}\text { Seagrass } \\
\text { species }\end{array}$ & $\begin{array}{l}\text { Geographical } \\
\text { area }\end{array}$ & Consumers & $\begin{array}{l}\text { Type and extent } \\
\text { of consumption }\end{array}$ & $\begin{array}{l}\text { Preferences } \\
\text { observed }\end{array}$ & Source \\
\hline \multicolumn{6}{|c|}{ Studies based on in situ observations (measurements on gut content of potential seagrass consumers) } \\
\hline $\begin{array}{l}\text { Posidonia spp., } \\
\text { Heterozostera } \\
\text { tasmanica, } \\
\text { Zostera muelleri, } \\
\text { Amphibolis } \\
\text { antarctica }\end{array}$ & $\begin{array}{l}\text { South coast of } \\
\text { Australia, from } \\
\text { Thomsons Bay to } \\
\text { Jervis Bay (30 lo- } \\
\text { calities) }\end{array}$ & $\begin{array}{l}\text { Gut contents of } 106 \\
\text { species were studied } \\
\text { and only Meuschenia } \\
\text { freycineti consumed } \\
\text { seagrass in substantial } \\
\text { quantities }\end{array}$ & 0 to $59.2 \mathrm{mg} \mathrm{m}^{-2} \mathrm{~d}^{-1}$ & $\begin{array}{l}\text { Seagrass was } \\
\text { possibly an } \\
\text { incidental item } \\
\text { ingested for its } \\
\text { associated sessile } \\
\text { invertebrates }\end{array}$ & $\begin{array}{l}\text { Edgar \& Shaw } \\
(1995)\end{array}$ \\
\hline $\begin{array}{l}\text { Posidonia } \\
\text { australis }\end{array}$ & $\begin{array}{l}\text { Port Hacking, } \\
\text { New South } \\
\text { Wales, eastern } \\
\text { Australia }\end{array}$ & $\begin{array}{l}39 \text { species of fish } \\
\text { community. Those } \\
\text { consuming seagrasses } \\
\text { and algae (7): Girella } \\
\text { tricuspidata, Petro- } \\
\text { scirtes lupus, } \\
\text { Monacanthus chinen- } \\
\text { sis, Meuschenia } \\
\text { freycineti, M. trachy- } \\
\text { lepis, Arothron hispi- } \\
\text { dus, Torquigener } \\
\text { pleurogramma }\end{array}$ & $\begin{array}{l}\text { Seven species } \\
\text { consumed algae } \\
\text { and seagrasses } \\
\text { (ca. } 10 \% \text { of the } \\
\text { overall community } \\
\text { diet). } 29 \text { to } 63 \% \text { gut } \\
\text { content of mono- } \\
\text { canthid fish }\end{array}$ & $\begin{array}{l}\text { Authors suggest } \\
\text { that fish grazed on } \\
\text { fauna-encrusted } \\
\text { Posidonia blades } \\
\text { and on their } \\
\text { attached epiphytic } \\
\text { algae }\end{array}$ & $\begin{array}{l}\text { Burchmore et } \\
\text { al. (1984) }\end{array}$ \\
\hline $\begin{array}{l}\text { Posidonia } \\
\text { australis }\end{array}$ & $\begin{array}{l}\text { New South } \\
\text { Wales, eastern } \\
\text { Australia }\end{array}$ & $\begin{array}{l}\text { Omnivorous fish: } \\
\text { Monacanthus chinen- } \\
\text { sis, Meuschenia } \\
\text { freycineti, M. trachy- } \\
\text { lepis }\end{array}$ & $\begin{array}{l}\text { Up to } 65 \% \text { of gut } \\
\text { content in } \\
\text { M. freycineti }\end{array}$ & $\begin{array}{l}\text { Preference towards } \\
\text { pieces with } \\
\text { encrusted bryo- } \\
\text { zoans and poly- } \\
\text { chaetes }\end{array}$ & $\begin{array}{l}\text { Bell et al. } \\
(1978)\end{array}$ \\
\hline $\begin{array}{l}\text { Posidonia } \\
\text { australis, } \\
\text { Amphibolis } \\
\text { antarctica }\end{array}$ & $\begin{array}{l}\text { Cliff Head, } \\
\text { Western Australia }\end{array}$ & $\begin{array}{l}\text { Crab: Portunus } \\
\text { pelagicus }\end{array}$ & $\begin{array}{l}\text { Low volume of } \\
\text { seagrass in gut } \\
\text { content }(6.1 \text { to } \\
23.2 \%)\end{array}$ & $\begin{array}{l}\text { Opportunistic } \\
\text { omnivores with } \\
\text { preferences for } \\
\text { slow-moving } \\
\text { animal prey }\end{array}$ & Edgar (1990) \\
\hline $\begin{array}{l}\text { Posidonia sinuosa, } \\
\text { P. coriacea, } \\
\text { Amphibolis } \\
\text { griffithii }\end{array}$ & $\begin{array}{l}\text { Fremantle, south- } \\
\text { western Australia }\end{array}$ & $\begin{array}{l}\text { Fish: Odax acrophilus, } \\
\text { Haletta semifasciata }\end{array}$ & $\begin{array}{l}0.3 \text { to } 17.1 \% \\
\text { volume in gut } \\
\text { content }\end{array}$ & $\begin{array}{l}\text { A. griffithii and } P \text {. } \\
\text { sinuosa, but no } P \text {. } \\
\text { coriacea }\end{array}$ & $\begin{array}{l}\text { MacArthur \& } \\
\text { Hyndes (2007) }\end{array}$ \\
\hline $\begin{array}{l}\text { Heterozostera } \\
\text { tasmanica } \\
\text { (Zosteraceae) }\end{array}$ & $\begin{array}{l}\text { Duck Point, } \\
\text { Corner Inlet, } \\
\text { south-eastern } \\
\text { Australia }\end{array}$ & $\begin{array}{l}\text { Fish (sea garfish): } \\
\text { Hyporhamphus } \\
\text { melanochir }\end{array}$ & $\begin{array}{l}35 \text { mg seagrass d } \\
\mathrm{g}^{-1} \mathrm{DW} \text { (body } \\
\text { weight) }\end{array}$ & Not specified & $\begin{array}{l}\text { Klumpp \& } \\
\text { Nichols (1983) }\end{array}$ \\
\hline \multicolumn{6}{|c|}{ Studies based on in situ observations (measurements on seagrass biomass consumption) } \\
\hline $\begin{array}{l}\text { Posidonia } \\
\text { australis }\end{array}$ & $\begin{array}{l}\text { Pittwater, Botany } \\
\text { Bay, Port Hack- } \\
\text { ing, south-east- } \\
\text { ern Australia }\end{array}$ & $\begin{array}{l}\text { Monocanthid fish: } \\
\text { Meuschenia freycineti, } \\
\text { M. trachylepis }\end{array}$ & $\begin{array}{l}\text { Direct consump- } \\
\text { tion. Low level of } \\
\text { grazing although } \\
\text { can result in high } \\
\text { localised removal } \\
\text { rates in certain } \\
\text { areas in winter } \\
0 \text { to } 2.4 \mathrm{mg} \text { DW } \\
\mathrm{m}^{-2} \mathrm{~d}^{-1}\end{array}$ & Not specified & $\begin{array}{l}\text { Wressnig \& } \\
\text { Booth (2008) }\end{array}$ \\
\hline $\begin{array}{l}\text { Posidonia } \\
\text { australis, } \\
\text { P. sinuosa }\end{array}$ & $\begin{array}{l}\text { Rottnest Island, } \\
\text { south-western } \\
\text { Australia }\end{array}$ & Isopods: Lynseia spp. & $\begin{array}{l}\text { Direct consumption } \\
\text { by burrowing } \\
\text { beneath the } \\
\text { epidermis and } \\
\text { consuming the } \\
\text { mesophyll and cells } \\
\text { of the vascular } \\
\text { bundles }\end{array}$ & $\begin{array}{l}\text { Preference for } \\
P \text {. australis leaves } \\
\text { over } P \text {. sinuosa } \\
\text { Preference for } \\
\text { ageing leaves }\end{array}$ & $\begin{array}{l}\text { Brearley \& } \\
\text { Walker (1995) }\end{array}$ \\
\hline
\end{tabular}


Table 5 (continued)

\begin{tabular}{|c|c|c|c|c|c|}
\hline $\begin{array}{l}\text { Seagrass } \\
\text { species }\end{array}$ & $\begin{array}{l}\text { Geographical } \\
\text { area }\end{array}$ & Consumers & $\begin{array}{l}\text { Type and extent } \\
\text { of consumption }\end{array}$ & $\begin{array}{l}\text { Preferences } \\
\text { observed }\end{array}$ & Source \\
\hline $\begin{array}{l}\text { Amphibolis } \\
\text { griffithii, } \\
\text { A. antarctica, } \\
\text { Posidonia spp., } \\
\text { Thalassodendron } \\
\text { pachyrhizum }\end{array}$ & $\begin{array}{l}\text { Western Australia } \\
\text { coastline (along } \\
1000 \mathrm{~km} \text { ) }\end{array}$ & $\begin{array}{l}\text { Isopod: Limnoria } \\
\text { agrostica }\end{array}$ & $\begin{array}{l}\text { Direct consumption } \\
\text { of new tissues } \\
\text { within the sheath } \\
\text { of } A \text {. griffithii }\end{array}$ & $\begin{array}{l}\text { Isopods preferen- } \\
\text { tially attacked } \\
\text { young tissues, the } \\
\text { most recently } \\
\text { apical clusters and } \\
\text { tissues within the } \\
\text { sheath area }\end{array}$ & $\begin{array}{l}\text { Brearley et al. } \\
(2008)\end{array}$ \\
\hline $\begin{array}{l}\text { Posidonia sinu- } \\
\text { osa, P. coriacea, } \\
\text { Amphibolis } \\
\text { griffithii, } \\
\text { A. antarctica }\end{array}$ & $\begin{array}{l}\text { Geographe Bay, } \\
\text { south-western } \\
\text { Australia }\end{array}$ & $\begin{array}{l}8 \text { potential grazing fish } \\
\text { species: Odax acro- } \\
\text { philus, O. cyanomelas, } \\
\text { Girella zebra, Sipho- } \\
\text { nognathus beddomei, } \\
\text { Meuschenia hippocre- } \\
\text { pis, Scobynichthys } \\
\text { granulatus, Polyspina } \\
\text { piosae, Torquigener } \\
\text { pleurogramma }\end{array}$ & $\begin{array}{l}\text { Direct consumption } \\
\text { by biting leaves. } \\
\text { Extremely low } \\
\text { level of seagrass } \\
\text { grazing }(0.00065 \% \\
\text { of the biomass in } \\
\text { the bay) }\end{array}$ & $\begin{array}{l}\text { No preference } \\
\text { towards leaves with } \\
\text { high nitrogen } \\
\text { content. Preference } \\
\text { for P. sinuosa and } \\
\text { A. griffithii over } \\
\text { A. antarctica }\end{array}$ & $\begin{array}{l}\text { White et al. } \\
\text { (2011) }\end{array}$ \\
\hline Posidonia sinuosa & $\begin{array}{l}\text { Cockburn Sound, } \\
\text { Western Australia }\end{array}$ & $\begin{array}{l}\text { Sea urchin: Temno- } \\
\text { pleuris michaelsenii }\end{array}$ & Not quantified & Not specified & $\begin{array}{l}\text { Cambridge et } \\
\text { al. (1986) }\end{array}$ \\
\hline Halophila ovalis & Western Australia & $\begin{array}{l}\text { Black swan: Cygnus } \\
\text { atratus }\end{array}$ & $\begin{array}{l}23 \% \text { of seagrass } \\
\text { production }\end{array}$ & Not specified & $\begin{array}{l}\text { Eklöf et al. } \\
\text { (2009) }\end{array}$ \\
\hline Posidonia sinuosa & $\begin{array}{l}\text { Marmion Lagoon } \\
\text { off Perth, } \\
\text { Western Australia }\end{array}$ & $\begin{array}{l}\text { Gastropods: Thalotia } \\
\text { conica } \\
\text { Amphipod: Tethy- } \\
\text { geneia spp., Ampithoe } \\
\text { spp., Hyale spp. }\end{array}$ & Not quantified & $\begin{array}{l}\text { Grazers did not eat } \\
\text { Posidonia leaves, } \\
\text { but ate their } \\
\text { epiphytes and } \\
\text { periphyton }\end{array}$ & $\begin{array}{l}\text { Jernakoff \& } \\
\text { Nielsen (1997, } \\
\text { 1998) }\end{array}$ \\
\hline \multicolumn{6}{|c|}{ Studies based on multiple-choice experiments } \\
\hline $\begin{array}{l}\text { Posidonia } \\
\text { australis }\end{array}$ & $\begin{array}{l}\text { Botany Bay, Port } \\
\text { Hacking, south- } \\
\text { eastern Australia }\end{array}$ & $\begin{array}{l}\text { Monocanthid fish: } \\
\text { Meuschenia freycineti, } \\
\text { M. trachylepis }\end{array}$ & Direct consumption & $\begin{array}{l}\text { Preference toward } \\
\text { seagrass leaves } \\
\text { with high epiphyte } \\
\text { loads (old leaves). } \\
\text { Young, soft, } \\
\text { nutrient-rich } \\
\text { seagrass blades } \\
\text { were consumed } \\
\text { less than mature } \\
\text { blades }\end{array}$ & $\begin{array}{l}\text { Wressnig \& } \\
\text { Booth (2007) }\end{array}$ \\
\hline $\begin{array}{l}\text { Posidonia } \\
\text { australis }\end{array}$ & $\begin{array}{l}\text { Shoalwater Bay } \\
\text { and Boyinaboat } \\
\text { Reef, south-west- } \\
\text { ern Australia }\end{array}$ & $\begin{array}{l}\text { Gastropods: Pyrene } \\
\text { bidentata, Cantharidus } \\
\text { lepidus }\end{array}$ & $\begin{array}{l}\text { Low level of } \\
\text { grazing on seagrass } \\
\text { leaves }(0.00-0.24 \\
\left.\text { mg ind. } .^{-1} \mathrm{~d}^{-1}\right)\end{array}$ & $\begin{array}{l}\text { Preference towards } \\
\text { kelp and periphy- } \\
\text { ton and red algae } \\
\text { and avoidance of } \\
\text { seagrass consump- } \\
\text { tion }\end{array}$ & $\begin{array}{l}\text { Doropoulos et } \\
\text { al. (2009) }\end{array}$ \\
\hline
\end{tabular}


Table 5 (continued)

\begin{tabular}{|c|c|c|c|c|c|}
\hline $\begin{array}{l}\text { Seagrass } \\
\text { species }\end{array}$ & $\begin{array}{l}\text { Geographical } \\
\text { area }\end{array}$ & Consumers & $\begin{array}{l}\text { Type and extent } \\
\text { of consumption }\end{array}$ & $\begin{array}{l}\text { Preferences } \\
\text { observed }\end{array}$ & Source \\
\hline \multicolumn{6}{|c|}{ Studies based on stable isotope techniques } \\
\hline $\begin{array}{l}\text { Amphibolis } \\
\text { griffithii }\end{array}$ & $\begin{array}{l}\text { Success Bank, } \\
\text { Western Australia }\end{array}$ & $\begin{array}{l}\text { Several fish species: } \\
\text { Cochleocepts sp., } \\
\text { Notolabrus parilus, } \\
\text { Acanthaluteres vittiger, } \\
\text { Scobinichthys granula- } \\
\text { tus, Odax acroptilus, } \\
\text { Siphonognathus ra- } \\
\text { diatus, Leviprora inops, } \\
\text { Pelates sexlineatus, } \\
\text { Pelsartia humeralis }\end{array}$ & Not quantified & $\begin{array}{l}\text { Macroalgae were } \\
\text { identified as the } \\
\text { main contributor of } \\
\text { carbon to the } \\
\text { trophic structure, } \\
\text { whereas seagrass is } \\
\text { the main contribu- } \\
\text { tor to seston and } \\
\text { sedimentary } \\
\text { organic matter, and } \\
\text { very little of it is } \\
\text { incorporated into } \\
\text { the trophic level }\end{array}$ & $\begin{array}{l}\text { Smit et al. } \\
(2005)\end{array}$ \\
\hline Posidonia sinuosa & $\begin{array}{l}\text { Fremantle, } \\
\text { Western Australia }\end{array}$ & $\begin{array}{l}\text { Gastropods: } \\
\text { Cantharidus lepidus, } \\
\text { Thalotia conica }\end{array}$ & Not quantified & $\begin{array}{l}\text { Authors suggest } \\
\text { that these gastro- } \\
\text { pods consumed } \\
\text { significant amount } \\
\text { of } P \text {. sinuosa leaves }\end{array}$ & $\begin{array}{l}\text { Smit et al. } \\
(2006)\end{array}$ \\
\hline $\begin{array}{l}\text { Posidonia } \\
\text { australis }\end{array}$ & $\begin{array}{l}\text { South-eastern } \\
\text { Australia }\end{array}$ & $\begin{array}{l}\text { Monocanthid fish: } \\
\text { Meuschenia freycineti, } \\
\text { M. trachylepis }\end{array}$ & Not quantified & $\begin{array}{l}\text { Epifauna and } \\
\text { epiphytes of } P \text {. } \\
\text { australis were the } \\
\text { main food source of } \\
\text { the } 2 \text { grazers }\end{array}$ & $\begin{array}{l}\text { Wressnig } \\
(2006)\end{array}$ \\
\hline
\end{tabular}

responsible for the relative low grazing on seaasses'. Our results suggested that not only the C:N composition but also the mechanical resistance, which was correlated with this ratio, may explain the low seagrass leaf palatability, as seagrasses generally exceed this $\mathrm{C}: \mathrm{N}$ ratio threshold.

The comparison of transverse versus longitudinal toughness across the species indicated that 2 to 4 times more work was required to fracture leaves transversely than longitudinally. The differences are due to fibre orientation in the leaf, since many veins lie longitudinally in monocot species (Onoda et al. 2011). To our knowledge, this is the first study to compare longitudinal and traversal toughness for a range of species. Ecologically, the high transverse toughness may influence the feeding behaviour of herbivores. For example, ingesting, grazing or detaching leaf blades by pulling them along the longitudinal axis may be easier in terms of energy consumption than doing so in the transverse axis. The longitudinal orientation of fibres may also explain the feeding behaviour of isopod miners in Posidonia spp. and Amphibolis griffithii, which burrow beneath the epidermis consuming the mesophyll and forming lin- ear mines along the longitudinal axis of the leaf lamina (Brearley \& Walker 1995).

In summary, we quantified mechanical resistance and nutritional value in a pool of 9 seagrass species. We confirmed the general assumption of the correlation between high $\mathrm{C}: \mathrm{N}$ ratio and high investment in structural reinforcement, and leaf toughening. Among co-existing seagrasses, we found a continuous spectrum of mechanical and nutritional traits across species, which will be useful as fundamental information of species assembly, herbivore behaviour and ecosystem functions. Further research on experimental feeding trials and multiple-choice experiments are required for more comprehensive understanding of the role of mechanical traits on animal-seagrass interactions.

Acknowledgements. We thank I. Wright for help with the shearing machine, as well as M. Westoby for use of the facilities at the Department of Biological Sciences (Macquarie University, Sydney) and for comments on the preliminary results. Also thanks to G. and D. Kendrick, J. Ooi, R. Hovey and J. Statton (The University of Western Australia, Perth) for help with field work, and J. Kuo for receiving us. We appreciate the constructive criticism given by 3 anonymous 
reviewers on the early version of the manuscript. Funds were provided by the projects Imachydro (CTM200800012/MAR) and Sea-Live (CTM2011-24482) from the Spanish Ministry of Science and Innovation, and by the Junta de Andalucía Excellence project PAMBIO (P08-RNM-03783). C.B.S. holds a contract within the project Imachydro. This is CEIMAR Journal publication no. 9.

\section{LITERATURE CITED}

Aragones L (1996) Dugongs and green turtles: grazers in the tropical seagrass ecosystem. PhD dissertation. James Cook University, Townsville

Aranwela N, Sanson G, Read J (1999) Methods of assessing leaf-fracture properties. New Phytol 144:369-383

Bell JD, Burchmore JJ, Pollard DA (1978) Feeding ecology of three sympatric species of leatherjackets (Pisces: Monacanthidae) from a Posidonia seagrass habitat in New South Wales. Aust J Mar Freshw Res 29:631-643

Birch WP (1975) Some chemical and calorific properties of tropical marine angiosperms. J Appl Ecol 12:69-80

$>$ Bjorndal KA (1980) Nutrition and grazing behaviour of the green turtle Chelonia mydas. Mar Biol 56:147-154

$>$ Brearley A, Walker DI (1995) Isopod miners in the leaves of two Western Australian Posidonia species. Aquat Bot 52: 163-181

> Brearley A, Kendrick GA, Walker DI (2008) How does burrowing by the isopod Limnoria agrostisa (Crustacea: Limnoriidae) affect the leaf canopy of the southern Australian seagrass Amphibolis griffithii? Mar Biol 156: 65-77

> Burchmore JJ, Pollard DA, Bell JD (1984) Community structure and trophic relationships of the fish fauna of an estuarine Posidonia australis seagrass habitat in Port Hacking, New South Wales. Aquat Bot 18:71-87

Cambridge ML (1999) Growth strategies of Rottnest Island seagrasses. In: Walker DI, Wells FE (eds) The seagrass flora and fauna of Rottnest Island, Western Australia. Western Australia Museum, Perth, p 1-24

Cambridge ML, Lambers H (1998) Specific area and functional leaf anatomy in Western Australia seagrasses. In: Lambers H, Poorter H, Van Vuuren MMI (eds) Inherent variation in plant growth. Physiological mechanisms and ecological consequences. Backhuys Publishers, Leiden, p 1-11

> Cambridge ML, Chiffings AW, Brittan C, Moore L, McComb AJ (1986) The loss of seagrass in Cockburn Sound, Western Australia. II. Possible causes of seagrass decline. Aquat Bot 24:269-285

> Carruthers TJB, Dennison WC, Kendrick GA, Waycott M, Walker DI, Cambridge ML (2007) Seagrass of south-west Australia: a conceptual synthesis of the world's most diverse and extensive seagrass meadows. J Exp Mar Biol Ecol 350:21-45

> Cingolani AM, Posse G, Collantes MB (2005) Plant functional traits, herbivory selectivity and responses to sheep grazing in Patagonian steppe grasslands. J Appl Ecol 42: 50-59

> Díaz S, Noy-meir I, Cabido M (2001) Can grazing response of herbaceous plants be predicted from single vegetative traits? J Appl Ecol 38:497-508

> Doropoulos C, Hyndes GA, Lavery PS, Tuya F (2009) Dietary preferences of two seagrass inhabiting gastropods: allochthonous vs autochthonous resources. Estuar Coast
Shelf Sci 83:13-18

Edgar GJ (1990) Predator-prey interactions in seagrass beds. II. Distribution and diet of the blue manna crab Portunus paleagicus Linnaeus at Cliff Head, Western Australia. J Exp Mar Biol Ecol 139:23-32

Edgar GJ, Shaw C (1995) The production and trophic ecology of shallow-water fish assemblages in southern Australia III. General relationships between sediments, seagrasses, invertebrates and fishes. J Exp Mar Biol Ecol 194:107-131

Eklöf JS, McMahon K, Lavery PS (2009) Effects of multiple disturbances in seagrass meadows: Shading decreases resilience to grazing. Mar Freshw Res 60:1317-1327

Gere JM, Goodno BJ (2009). Mechanics of materials, 7th SI edn. Cengage Learning, Toronto

Goecker ME, Heck KL Jr, Valentine JF (2005) Effects of nitrogen concentrations in turtlegrass Thalassia testudinum on consumption by the bucktooth parrotfish Sparisoma radians. Mar Ecol Prog Ser 286:239-248

> Grime JP, Cornelissen JHC, Thompson K, Hodgson JG (1996) Evidence of a casual connection between antiherbivore defence and the decomposition rate of leaves. Oikos 77:489-494

Jernakoff P, Nielsen J (1997) The relative importance of amphipod and gastropod grazers in Posidonia sinuosa meadows. Aquat Bot 56:183-202

> Jernakoff P, Nielsen J (1998) Plant-animal association in two species of seagrasses in Western Australia. Aquat Bot 60: 359-376

> Kirkman H (1985) Community structure in seagrasses in southern Western Australia. Aquat Bot 21:363-375

- Kirsch KD, Valentine JF, Heck KL (2002) Parrotfish grazing on turtlegrass Thalassia testudinum: evidence for the importance of seagrass consumption in food web dynamics of the Florida Keys National Marine Sanctuary. Mar Ecol Prog Ser 227:71-85

Klumpp DW, Nichols PD (1983) Nutrition of the southern sea garfish Hyporhamphus melanochir: gut passage rate and daily consumption of two food types and assimilation of seagrass components. Mar Ecol Prog Ser 12:207-216

Kuiper-Linley M, Johnson CR, Lanyon JM (2007) Effects of simulated green turtle grazing on seagrass abundance, growth and nutritional status in Moreton Bay, south-east Queensland, Australia. Mar Freshw Res 58:492-503

Lanyon JM (1991) The nutritional ecology of the dugong, Dugong dugon, in tropical north Queensland. PhD thesis, Monash University, Melbourne

Lanyon JM, Sanson GD (2006) Mechanical disruption of seagrass in the digestive tract of the dugong. J Zool 270: 277-289

Lanyon JM, Limpus CJ, Marsh H (1989) Dugongs and turtles: grazers in the seagrass system. In: Larkum AWD, McComb AJ, Shepherd SA (eds) Biology of seagrasses. A treatise on the biology of seagrasses with special reference to the Australian Region. Aquatic plant studies 2. Elsevier, Amsterdam, p 610-634

Lucas PW, Turner IM, Dominy NJ, Yamashita N (2000) Mechanical defences to herbivory. Ann Bot (Lond) 86: 913-920

MacArthur LD, Hyndes GA (2007) Varying foraging strategies of Labridae in seagrass habitats: herbivory in temperate seagrass meadows? J Exp Mar Biol Ecol 340:247-258

Mariani S, Alcoverro T (1999) A multiple-choice feedingpreference experiment utilising seagrasses with a natural population of herbivorous fishes. Mar Ecol Prog Ser 
189:295-299

McGlathery KJ (1995) Nutrient and grazing influences on a subtropical seagrass community. Mar Ecol Prog Ser 122: 239-252

McMillan C, Zapata O, Escobar L (1980) Sulphated phenolic compounds in seagrasses. Aquat Bot 8:267-278

- Molinari N, Knight C (2010) Correlated evolution of defensive and nutritional traits in native and non-native plants. Bot J Linn Soc 163:1-13

$>$ Nakaoka M, Aioi K (1999) Growth of seagrass Halophila ovalis at dugong trails compared to the existing withinpatch variation in a Thailand intertidal flat. Mar Ecol Prog Ser 184:97-103

Onoda Y, Westoby M, Adler P, Chong AM and others (2011) Global patterns of leaf mechanical properties. Ecol Lett 14:301-312

> Pennings SC, Carefoot TH, Siska EL, Chase ME, Page TA (1998) Feeding-preference of a generalist salt-marsh crab: relative importance of multiple plant traits. Ecology 79:1968-1979

Pérez-Harguindeguy N, Díaz N, Vendramini F, Cornelissen JHC, Gurvich DE, Cabido M (2003) Leaf traits and herbivore selection in the field and in cafeteria experiments. Austral Ecol 28:642-650

Phillips RC, McRoy CP (1980) Handbook of seagrass biology: an ecosystem perspective. Garland STPM Press, New York, NY

> Prado P, Heck KL Jr (2011) Seagrass selection by omnivorous and herbivorous consumers: determining factors. Mar Ecol Prog Ser 429:45-55

Prado P, Alcoverro T, Romero J (2010) Influence of nutrients in the feeding ecology of seagrass (Posidonia oceanica L.) consumers: a stable isotope approach. Mar Biol 157: 715-724

Preen A (1995) Impacts of dugong foraging on seagrass habitats: observational and experimental evidence for cultivation grazing. Mar Ecol Prog Ser 124:201-213

R Development Core Team (2010) R: a language and environment for statistical computing. R Foundation for Statistical Computing, Vienna. Available at www.Rproject.org

Read J, Sanson GD (2003) Characterising sclerophylly: the mechanical properties of a diverse range of leaf types. New Phytol 160:81-99

Read J, Stokes A (2006) Plant biomechanics in an ecological context. Am J Bot 93:1546-1565

Read J, Sanson GD, Caldwell E, Clissold FJ and others (2009) Correlations between leaf toughness and phenolics among species in contrasting environments of Australia and New Caledonia. Ann Bot (Lond) 103:757-767

Russel-Hunter WD (1970) Aquatic productivity: an introduction to some basic aspects of biological oceanography and limnology. Collier-Macmillan, London

Sanson G (2006) The biomechanics of browsing and grazing. Am J Bot 93:1531-1545

Sanson G, Read J, Aranwela N, Clissold F, Peeters P (2001) Measurement of leaf biomechanical properties in studies of herbivory: opportunities, problems and procedures. Austral Ecol 26:535-546

Siska EL, Pennings SC, Buck TL, Hanisak MD (2002) Latitudinal variation in palatability of salt-marsh plants: Which traits are responsible? Ecology 83:3369-3381

Smit AJ, Brearley A, Hyndes GA, Lavery PS, Walker DI

Editorial responsibility: Hans Heinrich Janssen,

Oldendorf/Luhe, Germany
(2005) Carbon and nitrogen stable isotopes analysis of an Amphibolis griffithii seagrass bed. Estuar Coast Shelf Sci 65:545-556

> Smit AJ, Brearley A, Hyndes GA, Lavery PS, Walker DI (2006) $\delta^{15} \mathrm{~N}$ and $\delta^{13} \mathrm{C}$ analysis of a Posidonia sinuosa seagrass bed. Aquat Bot 84:277-282

Thayer GW, Bjorndal KA, Ogden JC, Williams SL, Zieman JC (1984) Role of larger herbivores in seagrass communities. Estuaries 7(4A):351-376

Valentine JF, Duffy JE (2006) The central role of grazing in seagrass ecology. In: Larkum AWD, Orth LM, Duarte CM (eds) Seagrasses: biology, ecology and conservation. Springer, Dordrecht, p 463-501

Valentine JF, Heck KL Jr (1999) Seagrass herbivory: evidence for the continued grazing of marine grasses. Mar Ecol Prog Ser 176:291-302

> Valentine JF, Heck KL (2001) The role of leaf nitrogen content in determining turtlegrass (Thalassia testudinum) grazing by a generalized herbivore in the northeastern Gulf of Mexico. J Exp Mar Biol Ecol 258:65-86

Van Soest PJ, Robertson JB, Lewis BA (1991) Methods for dietary fibre, neutral detergent fibre, and non-starch polysaccharides in relation to animal nutrition. J Dairy Sci 74:3583-3597

> Vergés A, Becerro MA, Alcoverro T, Romero J (2007a) Experimental evidence of chemical deterrence against multiple herbivores in the seagrass Posidonia oceanica. Mar Ecol Prog Ser 343:107-114

Vergés A, Becerro MA, Alcoverro T, Romero J (2007b) Variation in multiple traits of vegetative and reproductive seagrass tissues influences plant-herbivore interactions. Oecologia 151:675-686

> Vergés A, Alcoverro T, Romero J (2011) Plant defences and the role of epibiosis in mediating within-plant feeding choices of seagrass consumers. Oecologia 166:381-390

White KS, Westera MB, Kendrick GA (2011) Spatial patterns in fish herbivory in a temperate Australian seagrass meadow. Estuar Coast Shelf Sci 93:366-374

Wressnig A (2006) Feeding ecology and role of two common seagrass (Posidonia australis) inhabiting fishes, the monocanthids Meuschenia freycineti and Meuschenia trachylepis. PhD thesis. University of Technology, Sydney

Wressnig A, Booth DJ (2007) Feeding preferences of two seagrass grazing monacanthid fishes. J Fish Biol 71: 272-278

Wressnig A, Booth DJ (2008) Patterns of seagrass biomass removal by 2 temperate Australian fishes (Monacanthidae). Mar Freshw Res 59:408-417

- Wright IJ, Cannon K (2001) Relationships between leaf lifespan and structural defences in a low-nutrient, sclerophyll flora. Funct Ecol 15:351-359

> Wright W, Vincent JFV (1996) Herbivory and the mechanics of fracture in plants. Biol Rev Camb Philos Soc 71: 401-413

Wright IJ, Peich PB, Westoby M, Ackerly DD and others (2004) The worldwide leaf economics spectrum. Nature 428:821-827

Zapata O, McMillan C (1979) Phenolic acids in seagrasses. Aquat Bot 7:307-317

Zieman JC, Iverson RL, Ogden JC (1984) Herbivory effects on Thalassia testudinum leaf growth and nitrogen content. Mar Ecol Prog Ser 15:151-158

Submitted: April 28, 2011; Accepted: April 16, 2012

Proofs received from author(s): June 26, 2012 